\title{
溶接継手の疲労き裂伝ぱのフラクトグラフィ
}

\author{
滳 内 良 雄* 吉 久 悦 二*
}

\section{Fractographic Study of Fatigue Crack Propagation in Butt-Welded Joints}

\author{
by
}

\section{Yoshio KitsunaI* and Etsuji Yoshinisa*}

Fatigue crack growth tests in butt-welded joints of HT80 and STS42 steels were carried out using compact type (CT), center-cracked tension (CCT) and single edge-cracked tension (SECT) specimens at room temperature and $173 \mathrm{~K}$, and their fracture surfaces were examined using a scanning and a transmission electron microscopes to evaluate the influence of residual stress on the formation of fracture morphologies.

As the fatigue crack propagated through compressive residual stress fields, the fracture surface was covered with a thin oxide film which was produced by mutual contact of crack surfaces. At $\Delta K$ above $20 \mathrm{MPa} \sqrt{\mathrm{m}}$ or the crack growth rate above $2 \times 10^{-8} \mathrm{~m} / \mathrm{cycle}$, the fracture morphologies in the base metal and welded joints were dominated by striations independent of the test temperature. At the low $\Delta K$ region or the crack growth rate below $1 \times 10^{-9} \mathrm{~m} / \mathrm{cycle}$, fracture morphologies showed that the fatigue crack propagated along the microstructures with favourite orientation to the crack growth. The intergranular like facets were formed in the weld metal of HT80 steel at $\Delta K$ ranging from 4 to 12 $\mathrm{MPa} \sqrt{\mathrm{m}}$. The maximum area percentage of the intergranular like facets, however, was considerably lower than that of intergranular facets formed in the base metal. The striation spacings in the welded joints were correlated well with the effective stress intensity factor range, $\Delta K_{\text {eff } \mathrm{R}}$, which was estimated by superposition of the respective stress intensity factors for the residual stress fields and for the applied stresses.

Key words : Welded-joint, Fatigue, Crack propagation, Fractography, Residual stress, Fracture mechanics

\section{1 結訔}

溶接部にはその製作過程において不溶着部やき裂状 の欠陥が作られることがあるが，このような欠陥を有 する溶接継手の疲労寿命は, き裂の発生よりも伝ぱ過 程に支配されると言われている．このため種々の材料 の溶接継手に対して， $\Delta K_{\mathrm{th}}$ から最終破壊に至るまで の疲労き裂伝ぱ特性が調べられて来た。 その結果, 疲 労き裂伝ぱ速度 $d a / d N$ は材料の強度や継手の形式な どよりも, 残留応力に強く影響されることが明らかに されている. 一方, 溶接継手の疲労破面についてもフ ラクトグラフィによる検討が行われているが，巨視的 観点からの研究に比べて少ない. したがって, 溶接継 手の微視的破壊機構を解明するためにも，また破壊事 故解析を行う上からも, 出来るだけ多くのデー夕を集 積することが必要と考えられる，本報では，HT80 鋼 ならびに STS42 鋼の室温と低温の疲労き裂伝ぱ過程 で出現する破面形態の特徵を残留応力との関連で調べ, さらに，溶接継手に形成されたストライエーションの 間隔と残留応力を考慮した有効応力拡大係数範囲との 相関について検討したもので, それらの結果について
報告する。

\section{2 . 試験片および実験方法}

供試材は板厚が $16 \mathrm{~mm}$ の HT80 鋼と肉厚が 32.5 $\mathrm{mm}$ の配管用鋼の STS42 のパイプであって，HT80 鋼では圧延方向と直角に幅 $300 \mathrm{~mm}$, 長さ $1830 \mathrm{~mm}$, 厚さ $16 \mathrm{~mm}$ に溶断後 X 開先加工を，また STS42 鋼 ではパイプから切り出した幅 $100 \mathrm{~mm}$, 長さ $600 \mathrm{~mm}$, 厚さ $27 \mathrm{~mm}$ の板の長手方向に沿って $\mathrm{X}$ 開先を付けた 後, HT80 鋼ではシールドメタルアーク溶接により, STS42 鋼ではサブマージアーク溶接により, Table I に示す条件で突合せ溶接を行った．溶接後，HT80 鋼

Table I. Welding conditions.

\begin{tabular}{l|l|l}
\hline \multicolumn{1}{c|}{ Parameter } & \multicolumn{1}{|c}{ HT80 } & \multicolumn{1}{c}{ STS42 } \\
\hline Groove & Double V & Double V \\
Position & Flat & Flat \\
Electrode & JIS D8016 & MF-38XUS36 \\
Current & $180-220 \mathrm{~A}$ & $600-650 \mathrm{~A}$ \\
Arc voltage & $35 \mathrm{~V}$ & $34-35 \mathrm{~V}$ \\
Welding speed & $180-220 \mathrm{~mm} / \mathrm{min}$ & $350-370 \mathrm{~mm} / \mathrm{min}$ \\
Number of runs & 6 & 9 \\
\hline
\end{tabular}



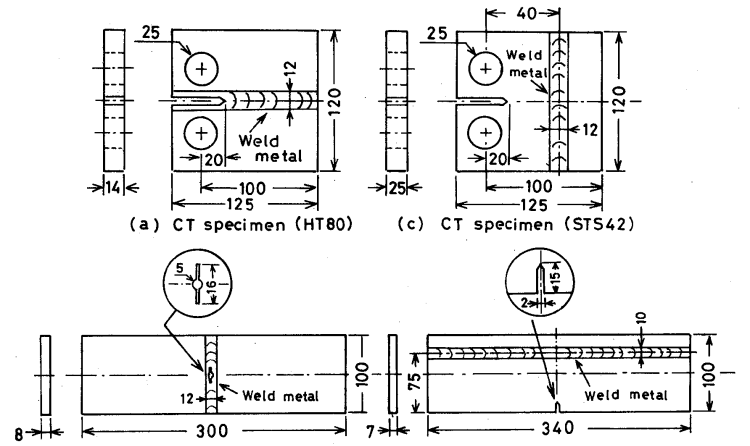

$\begin{array}{ll}\text { (b) CCT specimen (HT 80) } & \text { (d) SEC specimen (STS42) }\end{array}$

Fig. 1. Configurations of CT, CCT and SEC specimens.

板からはき裂が溶接金属中を伝ぱするように切り欠き を付けたCT（Fig.1(a)）とCCT（Fig. 1(b)) 試験片 を, STS42 鋼溶接板からはき裂が溶接金属を直角に 横切るように切り欠きを付けた CT (Fig. 1 (c)) と SEC（Fig. 1(d)）試験片を作製した. 母材試験片は Fig. 1 (a)の CT 試験片と同じ寸法に加工した. 疲労き 裂伝ぱ試験は, 低温槽を装着した電気油圧式サーボ疲 労試験機を用いて HT80 鋼では室温と $173 \mathrm{~K}$ で, STS42 鋼では室温で荷重制御による試験を実施した。 繰返し速度は 10 20 Hz である.なお, $173 \mathrm{~K}$ の温度 制御は低温槽に流入する液体窒素の量を電磁弁で調整 する方法によった．き裂長さの計測は室温では 50 倍 の光学顕微鏡により, また低温ではビーチマーク法と クラックゲージを併用した. 破面の観察には走査およ び透過電子顕微鏡を用いた. ストライエーション間隔 の測定には，二段レプリカを作成して透過電子顕微鏡 による撮影を行い, 特に $8 \times 10^{-8} \mathrm{~m}$ 以下の間隔のスト

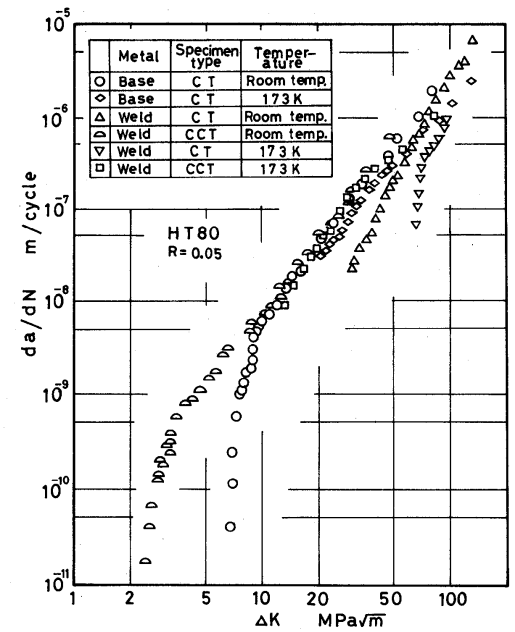

Fig. 2. Fatigue crack growth rates in base metal and weld metal of HT80 steel at room temperature and $173 \mathrm{~K}$ as a function of $\Delta K$.
ライエーションはネガを投影機で拡大することにより 間隔を計測した.

\section{3 実験結果および考察}

\section{$3 \cdot 1$ 疲労き裂伝ぱ挙動とマクロ破面形態}

Fig. 2 は室温と $173 \mathrm{~K}$ における HT 80 鋼の母材と溶 接金属の, Fig. 3 は室温における STS42 鋼の母材と 溶接継手の $d a / d N$ と $\Delta K$ の関係を示したもので, これらの多くはすでに他に報告しでている. なお, STS42 鋼のうち, Fig. 1 (c) に示した溶接 CT 試験片 ではFig. 4 に見られるように，き裂が溶接線を通過す る以前の母材側において，き裂前縁が板厚方向で大き く相違したために $d a / d N$ を求めることが困難であっ た.したがって，ここではそれらを示していない.

マクロ破面の様相は，材質や試験温度よりも試験片 の有する残留応力分布に依存しており, 初期圧縮残留 応力場をき裂が伝ぱした破面では，いずれもフレッチ ング酸化物が残されていた. Fig. 4 はその一例として, 試験片の切り欠き近傍に黒褐色のフレッチング酸化物

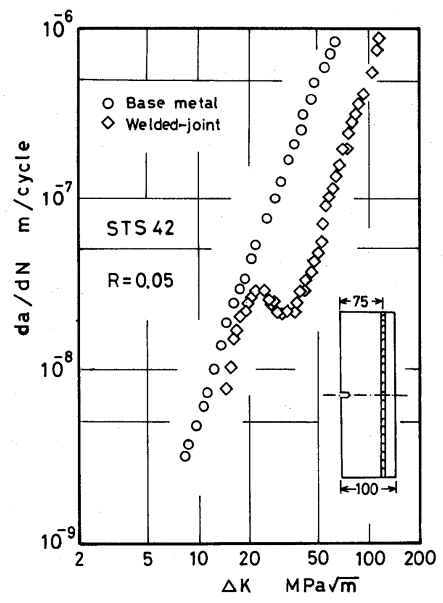

Fig. 3. Fatigue crack growth rates in base metal and welded-joint of STS42 steel as a function of $\Delta K$. 


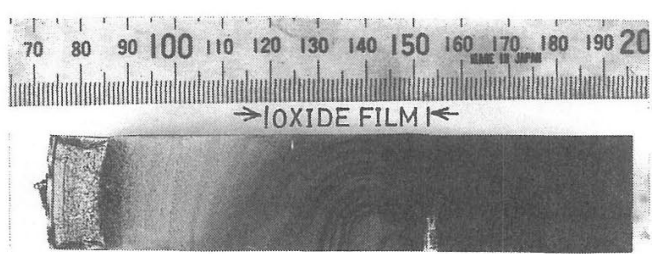

Fig. 4. Macro-fractograph showing oxide film formed on fracture surface in welded-joint of STS42 steel.

が厚く付着している STS42 鋼の溶接 CT 試験片 (Fig. 1 (c)）のマクロ破面を示したもので，先に報告 した縦溶接継手 CT 試験片の場合と同様溶接線前方 の母材側に強い圧縮残留応力が存在していたために, き裂の伝ぱに際してき裂面同志が強く接触しあってフ レッチング酸化物が形成されたと考えられる。このよ うなフレッチング酸化物は，き裂の先端に常に圧縮残 留応力が誘起される HT80 鋼の溶接 CT 試験片 (Fig. 1(a)）や切り欠きと溶接線との間に圧縮残留応力が存 在する STS42 鋼の SEC 試験片 (Fig. 1 (d))，および 母材の $\Delta K_{\mathrm{th}}$ 近傍の破面に残されていた。一方, HT80 鋼の溶接 CCT 試験片（Fig. 1 (b)）の破面には, $\Delta K_{\text {th }}$ 近傍においても，極くわずかなフレッチング酸
化物が付着しているだけであった。これは別報で示し たように, Fig. 1(b)のタイプの溶接 CTT 試験片では き裂の先端が常に引張り残留応力場に置かれるので, き裂面の接触がほとんど起こらないためである.

\section{$3 \cdot 2$ 溶接継手のミク口破面形態}

フレッチング酸化物に覆われていた Fig. 4 の破面に, 二段レプリカを適用して酸化物を除去後，破面観察を 行ったところ, 破面同志の接触を示すこすりあった様 相や，破面の特徽が消滅して無特徵となった領域がか なりの部分で認められた。しかし，損傷をほとんど受 けない部分も若干残されていた. Fig. 5 (a) は部分接触 破面を示したもので, 接触領域はフレッチング酸化物 が付着しているために，黒いファセット状を呈してい るのに対して, 非接触領域では白あるいは灭色状の稜 線模様が認められる。なお，これらのファセット上で は明瞭には見られないが，接触領域には試験片の面外 方向に平行な多数の線が残されている場合が多い.

Fig. 5 (b) は非接触領域の破面形態を示したもので, 低 伝ば速度域の特徴である組織敏感な様相が認められる。 これらをさらに詳細に見ると, 層状セメンタイトの間 のフェライトに微細なすべり線が作られており, き裂 がセメンタイトとフェライトの界面をセメンタイトの

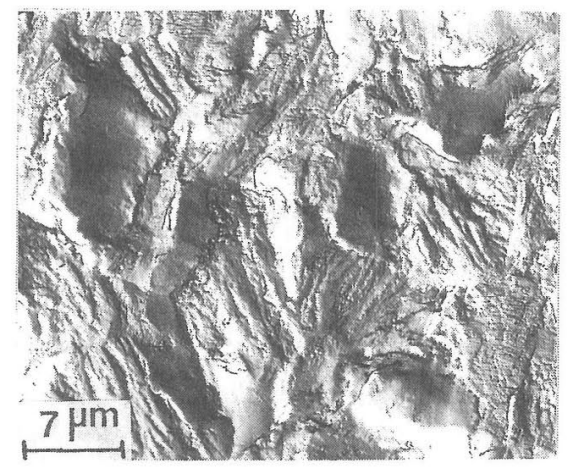

(a) Dark facets showing partial contact between adjacent crack surfaces.

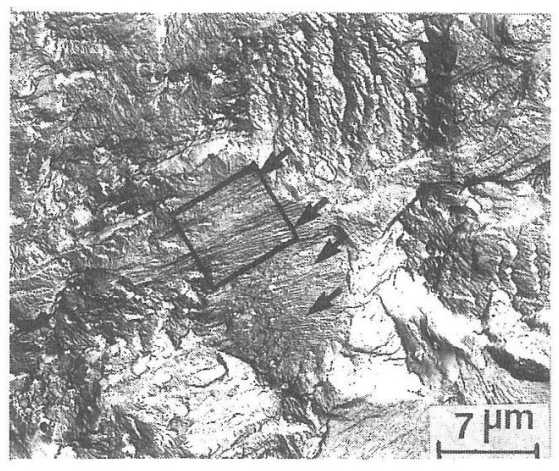

(b) Non-contacting fracture surface. Arrows indicate cementite band.

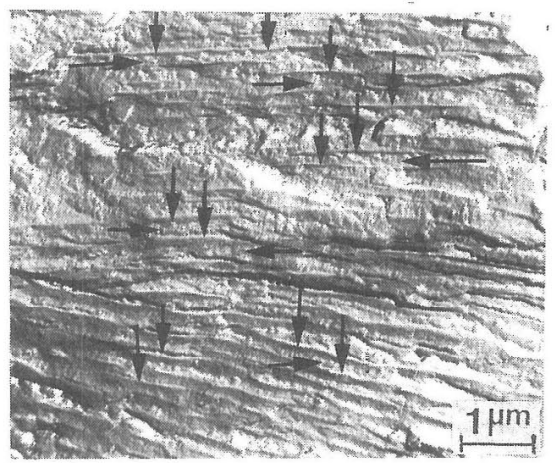

(c) Enlarged view of square in Fig. 5 (b).

Vertical arrows indicate cementite and horizontal arrows indicate slip lines in ferrite.

Fig. 5. Fractographs showing area locally covered with fretting oxide film. 


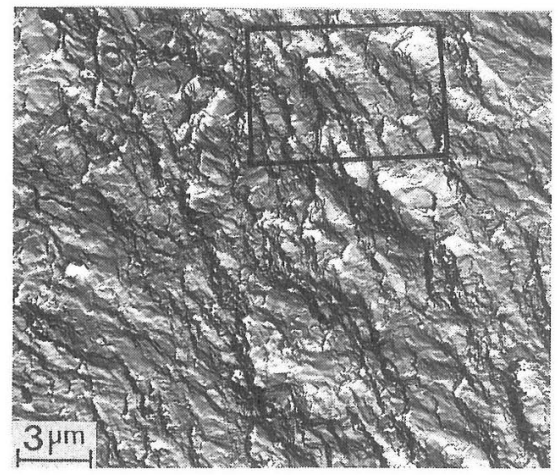

(a) Linear pattern which laid along crack growth direction.

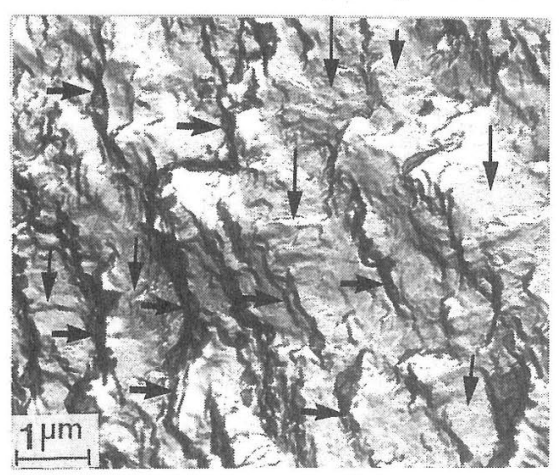

(b) Enlarged view of Fig. 6(a).

Vertical arrows indicate striation like pattern and horizontal arrows indicate linear pattern.

Fig. 6. Fractographs of near $\Delta K_{\text {th }}$ region ( $\Delta K$ $=2.8 \mathrm{MPa} \sqrt{\mathrm{m}}$ ) in weld metal of HT80 steel.

成長方向に沿って伝ぱしたことを示している（Fig. 5 (c)). このような破面形態の特徴は, 母材の $10^{-10} \sim$ $10^{-9} \mathrm{~m} /$ cycle 程度の低き裂伝ば速度域で出現する形 態と類似している。 な拉, ビーチマークから推定され る破面観察位置の $d a / d N$ は約 $5 \times 10^{-10} \mathrm{~m} /$ cycle と なっており，したがって圧縮残留応力場の破面形態は 母材の $d a / d N$ に対応した様相を古していることがわ かる. Fig. 6 (a) は HT80 鋼の溶接 CCT 試験片の $\Delta K_{\text {th }}$ 近傍の破面形態を示したもので，き裂の巨視的 伝ぱ方向（写真の右下から左上）とほほ同方向に複雑 に入り組んだ線条の模様が作られている。しかし， Masuda らが HT80 鋼溶接金属の $\Delta K_{\mathrm{th}}$ の破面の特長 として報告しているような非金属介在物を核とした気 孔は形成されておらず，また他に特徴的な形態も認め られない。なお, 気孔が形成されるか否かは, 溶接棒 や電流などの溶接条件に依存していると推察される. さらに高倍での観察では, Fig. 6 (b) に見られるように, 線状模様の間にき裂伝ぱ方向に向かって縞模様（ス卜 ライエーション状模様）が作られている。しかし, 縞

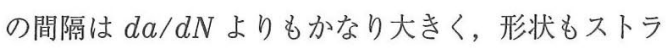
イエーションとは異なっている. これらの破面形態の 約 $3 \mathrm{~mm}$ 下部に存在する金属組織をナイタル腐食によ

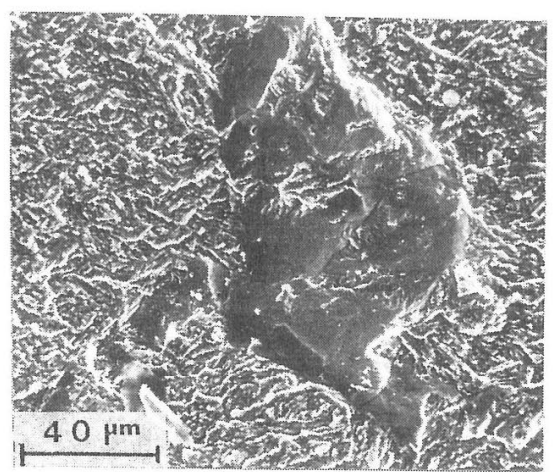

Fig. 7. Intergranular-like facets formed in weld metal of HT80 steel. $\Delta K=8.6 \mathrm{MPa} \sqrt{\mathrm{m}}$.

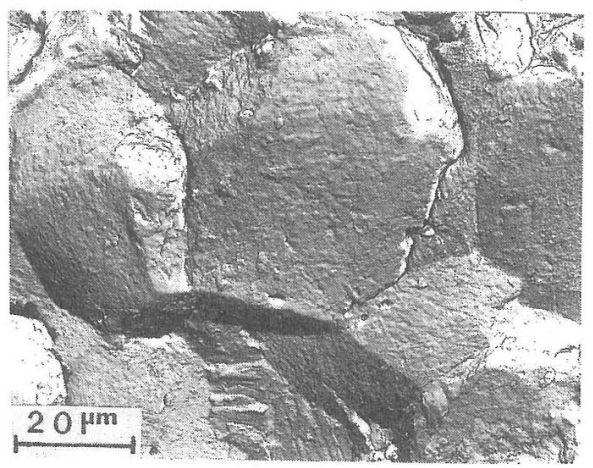

Fig. 8. Intergranular facets formed in base metal of HT80 steel. $\Delta K=12.3 \mathrm{MPa} \sqrt{\mathrm{m}}$.

り出現させ，破面形態と金属組織との関係について検 討した結果, 線状模様はべイナイトに, 縞模様はフエ ライトに対応する箇所に作られていた。このため，溶 接金属の $\Delta K_{\mathrm{th}}$ 近傍では，き裂は伝ぱ方向に方位する 組織（ベイナイト）に沿ってフェライト中をすべり変 形しながら伝ぱあるいは停止すると推察される。この ような低伝ぱ速度域におけるき裂の伝ぱ経路依存性は 破面粗さの増加に寄与し，き裂の閉口が助長されると 考えられる. da/dN が $1 \times 10^{-9} \sim 10^{-7} \mathrm{~m} /$ cycle の溶 接金属では，平滑なファセットを有する粒界状の様相 (Fig. 7) が出現する. しかしファセットの輸郭は，母 材に見られる粒界ファセット（Fig. 8) よりも明確で

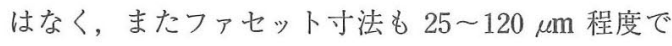
あって，母材のそれよりもかなりのばらつきを有して いる.この種の形態の成形機構については明らかでは ないが，このような低伝ば速度域ではき裂が強い組織 敏感性を示すことから，き裂が溶接金属中に形成され た微視組織の界面を通過したために形成された形態と 推察される。このファセットの破面率は，母材の粒界 ファセットの場合と同様, $d a / d N$ あるいは $\Delta K$ のレ ベルに対応して変化する. Fig. 9 は溶接金属のファ セットと, HT80 鋼母材に形成された粒界ファセット の破面率を $\Delta K$ に対してプロットしたもので，溶接 


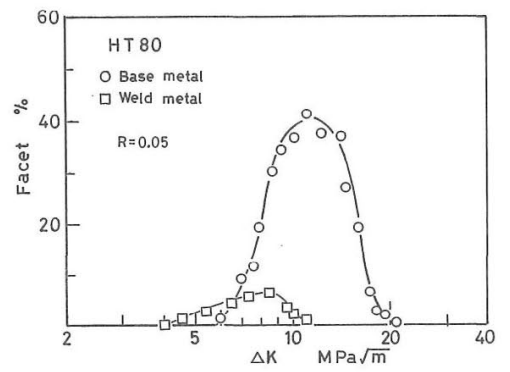

Fig. 9. Area percentage of intergranular-like facets in weld and intergranular facets in base metal of HT80 steel as a function of $\Delta K$. Both data were obtained by using CCT specimens.

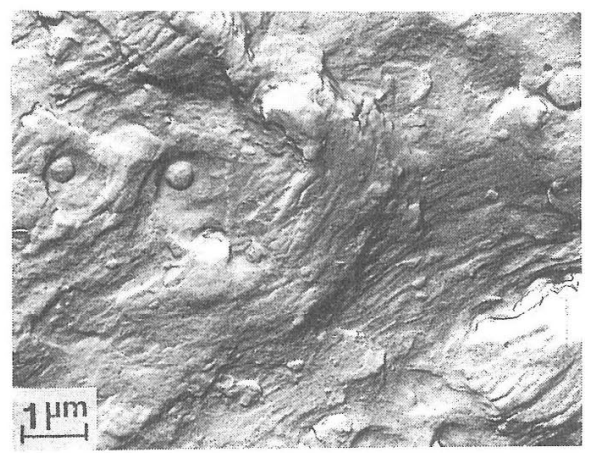

Fig. 10. Micro-voids associated with inclusions in weld metal of HT80 steel. $\Delta K=48.4 \mathrm{MPa} \sqrt{\mathrm{m}}$.

金属のファセット破面率は母材のそれに比べてかなり 小さく，また母材のように明確なピークは出現してい ない. $d a / d N$ が $1 \times 10^{-8} \mathrm{~m} /$ cycle 以上になると， ス トライエーション中に球状の介在物（Fig. 10) が出現 するようになり，特に高伝ぱ速度域では介在物を起点 としたディンプルが形成される。この介在物を X 線 マイクロアナライザで分析した結果，Mn-Si系の介 在物であった。以上は室温の結果であるが，低温 (173 K) においてもHT80 鋼の母材と溶接金属はス トライエーションが支配的な破面形態となっていた. なお，溶接金属の最終破壊の近傍では，室温の場合と 同様 $\mathrm{Mn}-\mathrm{Si}$ 系の介在物を核としたディンプルが形成 されていたが，へき開の介在は全く認められなかった。

\section{$3 \cdot 3$ 残留応力がストライエーション間隔に及ぼす 影響の評価}

Fig. 11 は HT80 鋼の母材と溶接金属のストライエ ーション間隔 $S$ と $\Delta K$ の関係を示したもので, $d a$ $/ d N$ と同様溶接 CT 試験片のストライエーション間 隔 $S$ は, 溶接 CCT 試験片や母材の $S$ よりも減少し ている. Fig. 12 はSTS42 鋼の母材と溶接継手の $d a$ $/ d N$ と $S$ を比較した結果であって, $S$ は $d a / d N$ に ほほ対応して変化している。これらの結果は， $S$ も $d a / d N$ と同程度に残留応力の影響を受けていること

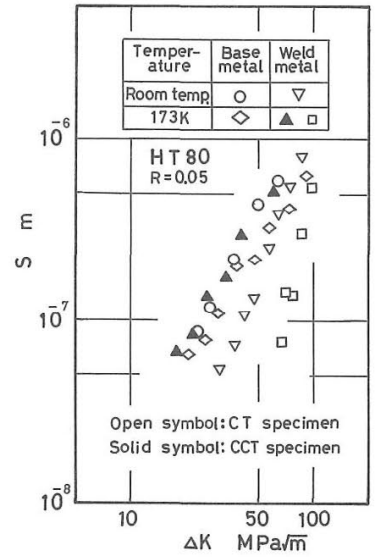

Fig. 11. Striation spacings in base metal and weld metal of HT80 steel at room temperature and $173 \mathrm{~K}$ as a function of $\Delta K$.

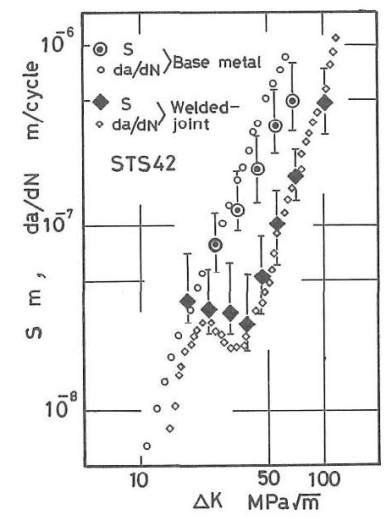

Fig. 12. Striation spacings in base metal and welded joint of STS42 steel as a function of $\Delta K$.

を示唆している。

残留応力場をき裂が伝ぱする場合, 残留応力の解放 に伴いき裂先端に応力拡大係数 $K_{\mathrm{R}}$ が誘起される.し たがって残留応力場の応力比 $R_{\text {res }}$ は, 外荷重による 最大と最小の $K$ 值に $K_{\mathrm{R}}$ を加算することにより式(1) のように表される.

$$
R_{\text {res }}=\left(K_{\min }+K_{\mathrm{R}}\right) /\left(K_{\max }+K_{\mathrm{R}}\right)
$$

残留応力場の $d a / d N$ は, 残留応力が $d a / d N$ に及ほ す影響を母材の応力比効果と等価であるとして, 残留 応力を考慮した有効応力拡大係数範囲 $\Delta K_{\text {eff R }}$ を用い て評価されている。

$$
\Delta K_{\text {eff } \mathrm{R}}=\left(\gamma+\delta R_{\text {res }}\right) \Delta K
$$

ここで， $\gamma$ と $\delta$ はき裂開口比 $U$ と応力比 $R$ の関係か ら定まる定数である.

式(2)の $\gamma$ と $\delta$ の值を定めるには，甘材の $S$ に及ぼ す $R$ の影響を $U$ との関係で調べる必要がある。そこ で， $R$ を変えて疲労き裂伝ぱ試験を行うと同時に $U$ を測定したHT80 鋼について， $S$ と $R$ の関係を調べ 


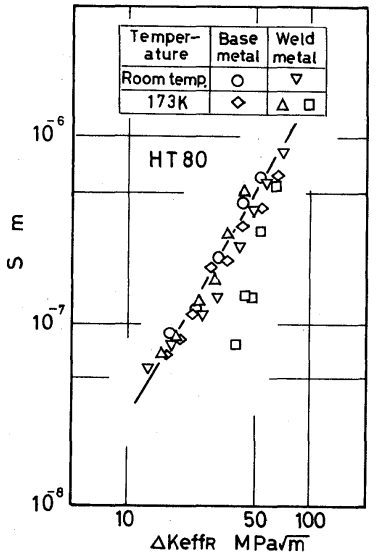

Fig. 13. Striation spacings in base metal and weld metal of HT80 steel at room temperature and $173 \mathrm{~K}$ as a function of $\Delta K_{\text {eff }}$.

た結果， $R$ の効果は $S$ のバラつきの範囲に包含され てしまい，両者の関係を明確に定めることが困難で あった．しかし，Fig. 12 に見られるように $S$ と $d a$ $/ d N$ はほぼ一致していることからここでは $S$ も $d a / d N$ と同程度の応力比効果を受けていると仮定し て， $d a / d N$ に対して定めた定数をそのまま適用した。 すなわち, HT 80 鋼の室温では $\gamma=0.85, \delta=0.25$,

$173 \mathrm{~K}$ では $\gamma=0.73, \delta=0.15, \quad$ STS 42 鋼では $\gamma$ $=0.82, \delta=0.3$ とした. ここで, 式(1)の $K_{\mathrm{R}}$ は, $\mathrm{CT}$ と SEC 試験片では片側切久きを, CCT 試験片では 中央切欠きを有する有限板のき裂面に集中荷重が作用 する場合の解を用いた．また，残留応力は別報で報告 したのと同様，計測した試験片の残留応力分布を多項 式近似により与えた.

Fig. 13 と 14 は, Fig. 11 と 12 に示した $S$ を $\Delta K_{\text {eff R }}$ に対して再プロットした結果であって，Fig. 13 では $173 \mathrm{~K} に$ における部のデータを除けばいずれも母材の データの周辺に表示される. 図中の実線は母材の $\mathrm{S}$ に対する直線近似結果である. STS 42 鋼でも， $S$ に 対してレプリカが十分な分解能を有する $5 \times 10^{-8} \mathrm{~m}$ 以 上では母材と溶接継手の $S$ が一致して扔り, $d a / d N$ の場合と同様 $S$ においても $\Delta K_{\text {eff R }}$ による整理が有効 であることがわかる.なお， $173 \mathrm{~K}$ の一部のデー夕は $\Delta K_{\text {ef } \mathrm{R}}$ との間に相関が成立するとは言い難いが, こ れは各試験片で残留応力が異なるにもかかわらず， 1 本の試験片の残留応力分布を用いて $K_{\mathrm{res}}$ を算出して いるためと推察される.

\section{4 結 論}

（1）き裂が圧縮残留応力場を伝ぱする場合，あるい はき裂先端に圧縮残留応力が誘起される場合，破面同 志の接触により，フレッチング酸化物が破面に残され る.なお, 残留応力を有する溶接金属のミク口疲労破

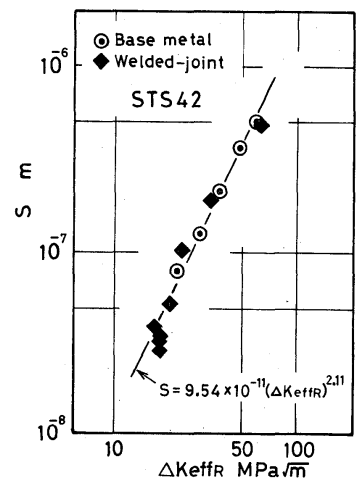

Fig. 14. Striation spacings in base metal and welded joint of STS42 steel as a function of $\Delta K_{\text {effR }}$.

面は，一部を除き母材の $d a / d N$ にほほ対応した形態 が出現する.

(2) $d a / d N$ が $5 \times 10^{-8} \mathrm{~m} /$ cycle 以上における $\mathrm{HT} 80$ 鋼の母材と溶接金属の疲労破面は, 室温と 173 $\mathrm{K}$ のいずれもストライエーションが支配的となって おり，温度による破面形態の差異は認められない。

（3）残留応力を有する溶接継手に形成されるストラ イエーションの間隔は, 残留応力を考慮した有効応力 拡大係数範囲と良い相関がある.

（4）溶接金属の $\Delta K_{\mathrm{th}}$ 近傍のき裂伝ぱ経路は，き裂 の伝ぱに好都合な方位を有する組織に沿っている.

（5）溶接金属においても母材と同様，低き裂伝ぱ速 度域に扔いて粒界状のファセットが形成される。しか し，その破面率は母材のそれよりもかなり小さく，ま たピークも明瞭ではない。

（昭和63年 6 月 17 日 第 6 回フラクトグラフィシンポジウムにて講演）

\section{参 考 文 献}

1) 石原 守, 平石茂樹, 杉本威生, 材料, 27, 42 (1978).

2 ) 橘内良雄, 材料, 32, 1376 (1983).

3 ) W. J. Mills and L. A. James, J. Enging. Mater. and Tech., 107, 41 (1985).

4 ) C. Masuda, H. Sumiyoshi, M. Kosuge, A. Ohta and S. Nishijima. Int. J. Fatigue, 9, 233 (1987).

5 ）橘内良雄, 吉久悦二, 日本機械学会論文集, A - $\mathbf{5 3}$, 1525 (1987).

6 ）橘内良雄, 小林英男, 成本朝雄, 石塚哲夫, 飯田國廣, 吉久悦二, 材料， 36，1077 (1987).

7) H. Tada, P. C. Paris and G. R. Irwin, "The Stress Analysis of Cracks Handbook", 2.27, 2.33 (1985) Del Research Co. 